\title{
CHARACTER BUILDING IN THE APPLICATION OF COLABORATIVE STRATEGIC READING IN READING CLASS
}

\author{
Putu Ayu Paramita Dharmayanti \\ Faculty of Teacher Training and Education \\ Mahasaraswati Denpasar University \\ Email: ayuparamita77@yahoo.com
}

\begin{abstract}
This research used descriptive qualitative design that aimed at describing character education values that were built in the application of Collaborative Strategic Reading. As the focus of this study was third grade university students who took Intermediate Reading lecture in English Education Study Program, Faculty of Teacher Training, Mahasaraswati Denpasar University. The data obtained in this study are qualitative data. The qualitative data were collected by observation, open questionnaire and guided interview. Data were collected by using researcher as the key instrument and some research instruments such as, field note, list of open questionnaire questions, and list of guided interview questions. The result of observation, open questionnaire and guided interview were analyzed descriptively using Interactive Model. The result of the study concluded that directly application of Collaborative Strategic Reading could build some values of character education, such as curiosity, creativity, communicative, responsible, hard work, love reading, discipline, and democratic but indirectly application of Collaborative Strategic Reading could build all values of character education through the moral value inserted in each text read by the reader.
\end{abstract}

Keywords: Character Building, Collaborative Strategic Reading, Reading Class

\begin{abstract}
ABSTRAK
Penelitian ini menggunakan desain kualitatif deskriptif yang bertujuan menggambarkan nilai-nilai pendidikan karakter yang dibangun dalam penerapan Strategi Membaca Kolaboratif. Sebagai fokus dari penelitian ini adalah siswa kelas tiga yang mengambil kuliah Membaca Menengah di Program Studi Pendidikan Bahasa Inggris, Pelatihan Fakultas Guru, Universitas Mahasaraswati Denpasar. Data yang diperoleh dalam penelitian ini adalah data kualitatif. Data kualitatif dikumpulkan dengan observasi, kuesioner terbuka dan wawancara terpimpin. Data dikumpulkan dengan menggunakan peneliti sebagai instrumen utama dan beberapa instrumen penelitian seperti, catatan lapangan, daftar pertanyaan kuesioner terbuka, dan daftar pertanyaan wawancara terpandu. Hasil observasi, angket terbuka dan wawancara terbimbing dianalisis secara deskriptif menggunakan Model Interaktif. Hasil penelitian menyimpulkan bahwa penerapan langsung Bacaan Strategis Kolaboratif dapat membangun nilai-nilai pendidikan karakter, seperti rasa ingin tahu, kreativitas, komunikatif, bertanggung jawab, kerja keras, membaca cinta, disiplin, dan demokratis tetapi secara tidak langsung penerapan Strategi Membaca Kolaboratif dapat membangun semua nilai pendidikan karakter melalui nilai moral yang dimasukkan dalam setiap teks yang dibaca oleh pembaca.
\end{abstract}

Kata kunci: Pembangunan Karakter, Strategi Membaca Kolaboratif, Kelas Membaca 


\section{INTRODUCTION}

The problem of moral deficiency and destructive behavior of students has become a world concern now. This raises some opinions about the importance of character education to be more emphasized in the teaching and learning activity. In line with this, Berkowitz and Bier stated that character education is not optional in the school; it is inevitable and therefore merits intentional focus and priority status in the school. In Indonesia, character education has also became current issue since 2011 which was firstly announced by Indonesian Government who declares 18 values of character education that should be inserted in Indonesian education. Those values of character education are religious, honesty, tolerant, discipline, hard work, creativity, autonomous, democratic, communicative, curiosity, nationalism, affection to mother land, appreciate achievement, social awareness, environmental awareness, peace, responsibility and love reading (Kemendiknas, 2011).

Actually character education is not something new. It is as old as the education itself. However, it has different challenges for every years and decades. The implementation of character education often encounters obstacles and even fails. According to Ali Muhtadi, in the article Strategies To Implement Effective Character Education at School (tt), there are several factors why character education experienced a "failure", ie, the first, still in force in educating the public that, especially moral education only the responsibility of educators, more specialized teachers. Second, the poor ability of educators to develop, let alone integrate moral values and character into other subjects. Third, the learning process is still conventional likely to only transfer of knowledge, let alone a source of learning only from the teacher, so that the learners the opportunity to develop the learning process with a variety of independent activity corresponding real life is getting limited. There for a selection of a teaching strategy which underlies studentcentered learning and characteristic education is necessitated.

Love reading is one of character educations that must be built. Ironically, reading in non-native language requires extra efforts and seems hard for EFL students to understand passages written in foreign languages. It makes students willingness in reading in foreign language is low. It becomes concern to improve that willingness because reading in foreign language is very important in this global era. Based on interview with the lecturer the students are able to comprehend and analyse immediate level text critically and able to make summary of the text is the standard competence of Intermediate Reading lecture in English Education Study Program, Faculty of Teacher Training and Education, Mahasaraswati Denpasar University as stated in the syllabus. Intermediate Reading is the immediate level of reading class inthis study program. The ability to analyse the text critically becomes an indicator to pass the lecture. Based on pre-observation, it was found that the reading classes were gathered by Collaborative Strategic Reading. The lecturer chose that strategy to encounter previously problems that were faced by the students in reading. One of the problems 
was the low mastery of vocabulary of the students. It brought the students to the next problems, such as hard to comprehend a text, easy to get bored when facing the text, unmotivated in joining the class, and the low willingness to read.

Collaborative Strategic Reading (CSR) was found and developed by Klinger \& Vaughn (1987). CSR is the comprehension strategy which combine modification of Reciprocal Teaching (RT) (Palincsar \& Brown, 1984) and Cooperative Learning (CL) strategy (Johnson \& Johnson, 1987).The concept of this strategy is engaging students to use comprehension strategies while working cooperatively. comprehension strategies include Preview,

Click \& Clunk, Get the Gist and Wrap Up. Preview allows students to generate interest and activate background knowledge in order to predict what they will learn. Click \& Clunk are self- monitoring strategy which controls their understanding about words, concepts and ideas that they understand or do not understand or need to know more about. Get the Gist. Students identify the main ideas from reading to confirm their understanding of the information. Wrap $\boldsymbol{U p}$ provides students with an opportunity to apply meta cognitive strategies (plan, monitor and evaluate) for further extend comprehension (Elkaumy, 2004). Figure 1 describes the four steps of CSR, Adopted from Sopris West Educational Services (Klinger et al., 2010). The goals of CSR are to improve reading comprehension and increase conceptual learning in ways that maximize students' involvement.

Previous study on improving students' reading ability using CSR show that this method is very effective to made the students (1) build their vocabulary; (2) encourage their high levels of comprehension; (3) learn in a meaningful context; and (4) have motivation to read. Based on the result of those previous studies, researcher conducted a research on what character education values that were built in the application of CSR. The researcher had a purpose on describing character education values that were built in the application of Reading Aloud Strategy in reading class.

\section{DISCUSSION}

From the three methods of data gathering, the researcher used observation to see the application of Reading Aloud Strategy in the class of the focus study that was the students who took Intermediate Reading lecture in class of III A and III B. They were 35 students in a class. The reading classes were conducted in three stages, which are traditionally labeled as presentation, practice, and production stages:

1. Presentation Stage.

With preview strategy, students preview the entire passage which is divided into 2 activities: brainstorming and predicting. The goals of previewing are activating students' background knowledge about the topic, help students to predict about what they will learn and motivating students' interest to the text that they will read.

2. Practice Stage.

In this stage, students become involved in cooperative learning. 
The instructor has students to form small groups with five members in each. Students are then asked to read their selected reading material (one paragraph or two at a time) while acting their specified roles:

a. Leader: Leads and directs the group during the implementation of CSR with the teacher's assistance, if needed, and keeps the group's members on task.

b. Clunk expert: Uses clunk cards to show the group the fix-up strategies when they try to figure out a clunk.

c. Gist Expert: Guides the group to identify the most important ideas of the passage they are reading.

d. Encourager: Encourages the group members participate in the group's discussion and gives the feedback.

e. Announcer: Calls on the group members to read or share ideas during the activity.

f. Reporter: Share the group's ideas, answers, and questions during a whole class discussion.

Students monitor their understanding and decide if they really understand what they read or not during reading. When students read a passage with understanding, they proceed smoothly through the text. When students find a word, concept, or idea hard to understand, it is a clunk. Clunks break down reading comprehension and make it hard to understand the whole text. In this case, students need to identify the clunks then figure them out using fix- up strategies, written on clunk cards, to understand the text. The steps of Fix-up strategies: (a) reread the sentence to determine the unknown word; (b) reread the sentence before and after the difficult word to look for the clues; (c) look for a prefix or suffix in the unknown word; (d) break the unknown word and look for smaller words that you know; (e) identify the text structure; and (f) identify the connective words.

In the following step, students move on to use get the gist strategy which students get involved in the processes of identifying the most important idea, the main sentence, and the specific information in a section of text (usually a paragraph). The goals of get the gist strategy is improving students' memory of what they have read so they can restate the most important point in their own words as a way of making sure they have understood what they have read.

3. Production Stage.

By using wrap-up strategy, the instructor asks students to do the following activities within their groups once the whole text 
is read: generating question for interviewing with each other on the reading material; retelling what s/he has read after summarizing the text; and performing pro-con debates about the topic. The goals are to improve students' knowledge, understanding, and memory of what was read.

Based on the observation, students enjoy working together. Small group activities promote students to be active, communicative, collaborative as well as cooperative in achieving similar learning goals. The most important is students feel more comfortable and confidence when working in small group because they can express their ideas freely. It is related to the underpinning theories of CSR are interactive, cognitive-constructivist, and the social constructivism perspectives. Knowledge and meaning can only be derived when the reader either interacts with the text alone or constructs its meaning with others. When students interact with texts, they use their prior knowledge, acquire information from the context, and combine disparate elements into a new whole before they arrive at their own idea of meaning. Meanwhile, in the process of interacting with others, the learning takes place in a socio cultural environment (students to student or student to teacher) through dialogue.CSR is the instructional use of small groups so that the students work together to maximize their own and each other's learning. This is in line with Vygotsky's socio cultural theory (1934), as stated in Graves, Juel, and Graves (2007), in which learning takes place in an interactive environment. The main point is that without interaction in order to construct meaning and understanding, learning does not take place.

To support the result of observation, the researcher distributed open questionnaire questions about students' response before, while, and after the application of CSR. Based on the result of open questionnaire, the students stated that before the application of CSR, they felt lazy to read because they found so many difficult words in a text that made them did not want to continue their reading. After the application of CSR, they can overcome the problem using Fix-Up strategy in Click and Clunk activity. By using Fix-Up strategy, they felt that they increase their curiosity and hard work. When they finally found the meaning of the difficult word, they feel challenging to find the meaning of the other difficult words even though it needed their effort and hard work. In addition, they felt all strategies in CSR can help them to comprehend the text easily. Unconsciously, they had a willing to read.

After getting the result of the observation and open questionnaire, the researcher confirmed it by conducting guided interview, so that the researcher could dig detail information about the problem. Result of the interview strengthen that students felt helpful by this method, especially in Click and Clunk Activity by using Fix-Up Strategy. It forced the students to search for the meaning of the difficult words in order to comprehend the text. Moreover, by doing activity in a group, they learned how to work cooperatively. The value of democracy is also felt by them in 
group where each student in the group gets their own job. It is also increase their autonomous, discipline, hard work, and responsibility to do their job right and on time. In line with that, CSR is taught meta cognitively by principle of planning, selfmonitoring, and evaluating. It is supported by Elkaumy (2004) that defines meta cognitive strategies in there ways: Planning, self-monitoring and evaluating or think about thinking. Planning is having reading purpose in mind to read the text in order to be more selective and focus the desired information. Self-monitoring is regulating the reading process and using the strategy at the right time. Evaluating is controling whether the purpose is reached or not.In addition, because every student experienced almost the same process in the group while applying CSR, they became tolerant to their friends.

At the end, Collaborative Strategic Reading as combine modification of Reciprocal Teaching and Cooperative Learning brought meaningful and contextual environment to read. That condition did not only make the students comprehend the text well but also it built the students' willingness to read being a habit so that the students love reading. Besides, the other essential of character education values that were built in application of CSR also could be clearly identified.

\section{CONCLUSION}

From the result of the data analysis, it could be drawn conclusion that directly application of Collaborative strategic Reading could build some values of character education. Each strategy in CSR builds different values of character education. Fix-Up Strategy build students curiosity and hard work. As cooperative learning, CSR builds values of tolerant, discipline, autonomous, democratic, communicative, appreciate achievement, social awareness, and responsibility. Over all, CSR make students love reading unconsciously. On the other side, indirectly application of CSR could build all values of character education through the moral value inserted in each text read by the reader.

Based on the result of the study, it is suggested to the university to use this result of study as valuable information for improving university quality, since the result of this study give one alternative teaching method in reading class that do not only build the cognitive of the students but also the characters; it is also suggested to the other researchers to use this result of research as reference for further research in the area of study; and finally it is suggested to the teachers or lecturers who teach reading to use Reading Aloud Strategy to build students' ${ }^{6}$ willingness to read as proven by this research.

\section{REFERENCES}

Berkowitz, M. W. (2000). Character education as prevention (pp.37-45). In W. B. Hansen, S. M. Giles, and M. D. Fearnow-Kenney (Eds.), Improving prevention effectiveness.Greensboro, NC: Tanglewood Research.

Dharmawan, N.S. (2014). Implementasi Pendidikan Karakter Bangsa Pada Mahasiswa Di Perguruan Tinggi. A paper presented at Character Education 
Supervising for University Students at Kopertis Wilayah VIII

ElKaumy, A.S.K. (2004). Metacognition and reading comprehension: current trends in theory and research, (online at www.eric.ed.gov).

Graves, M. F., Juel, C., and Graves, B. B. (2007). Teaching Reading in the $21^{\text {st }}$ Century, $4^{\text {th }} E d$. New Jersey: Pearson Education, Inc.

Kagan, S. (1994). Cooperative Learning. San Juan Capistrano, CA.

Kemendiknas. (2011). Panduan Pelaksanaan Pendidikan Karakter. Badan Penelitian dan Pengembangan Pusat Kurikulum dan Perbukuan: Jakarta.

Klinger, J.K and Vaughn, S. (1988). Using CSR. Retrieved June 2012, from http://www.idonline.org/idindepth/teach ing technique/collabreading.html.

Klinger, J. K., \& Vaughn, S. (1996). Reciprocal Teaching of Reading
Comprehension Strategies for Students with Learning Disabilities Who Use English as a Second Language. Elementary School Journal.96.275-293.

Klingner, J. K., \& Vaughn, S. (2000). The helping behaviors of fifth-graders while using collaborative strategic reading (CSR) during ESL content classes. TESOL Quarterly, 34, 69-98.

Klingner, J. K., Vaughn, S., Dimino, J., Schumm, J. S., \& Bryant, D. P. (2001). From clunk toclick: Collaborative Strategic Reading. Longmont, CO: Sopris West.

Suryaman, M. (2010). Pendidikan Karakter melalui Pendidikan Sastra. An Article in Cakrawala Pendidikan Journal. Th. XXIX, Dies Natalis of UNY Special Edition. Trelease, Jim. 2006. The ReadAloud Handbook. New York: Penguin Putnam. 